\title{
The Influence of Politeness Strategies on Visibility in I, Daniel Blake
}

\author{
Benita Lehmann*
}

\begin{abstract}
In I, Daniel Blake (2016), British filmmaker Ken Loach points to topics of social injustice and inequality in contemporary British society. Loach explores the inadequacies of the British welfare system and the problems of those who are being left behind and blamed for their situation, following what researchers have termed the 'underclass' approach (Madanipour et al. 2015). The film highlights the welfare system's dysfunctionalities through the main characters Daniel (Dave Johns), a 59-year old carpenter, having suffered a heart attack, and Katie (Hayley Squires), a single mother of two, who both fall victim to a social system that should support them but instead blames them for their situation.

This paper, then, examines how face work and politeness strategies influence the conversations taking place in the film and how these lead to the characters' enhanced (in)voluntary (in)visibility. I argue that visibility (Brighenti 2007 and 2010) and face work (Brown and Levinson 1999) interact and produce heightened (in)voluntary visibilities. This is particularly relevant, as visibility has become a major discourse within surveillance and digitisation both thriving on exposure and allegedly omnipresent visibility. In the film, as I argue, this is contrasted against the invisibility and impermeability of the social welfare system and the state.
\end{abstract}

\footnotetext{
* University of Innsbruck; benita_lehmann@gmx.net
} 
Ultimately, this paper suggests that bald on-record strategies (Brown and Levinson 1999) are used to expose claimants and keeping face is used as a strategy that strongly characterises scenes that highlight the importance of empathy.

Key words: Visibility, face work, politeness strategies, social injustice, Ken Loach, British welfare system, underclass approach

\section{Introduction}

Ken Loach's film I, Daniel Blake (2016) is a powerful testament to one man's struggle against the impenetrable machinery of the social welfare system in the UK. It highlights how Daniel (Dave Johns), a 59-year old carpenter, having suffered a heart attack, and Katie (Hayley Squires), a single mother of two, fall victim to a social system that should support them but instead blames them for their situation. I am primarily interested in the approach of face work and its implications for the category of visibility within in the film. My goal is to demonstrate how face work and politeness strategies influence the conversations taking place in the film and how these lead to the characters' enhanced (in)voluntary (in)visibility. This is particularly relevant, as visibility has become a major discourse within surveillance and digitisation both thriving on exposure and allegedly omnipresent visibility. In the film, as I argue, this is contrasted against the invisibility and impermeability of the social welfare system and the state.

Therefore, I will outline the notion of visibility as proposed by Andrea Brighenti (2007 and 2010) and his suggestion to consider the term as a category in the social sciences. Subsequently, I will summarise Brown and Levinson's framework for face work. Other approaches will be taken into consideration in order to frame the influence of social class and power relations. This forms the basis for the analysis of selected scenes from the film. The written manuscript serves as material for the analysis. I decided to keep entire passages in the analysis as it simplifies the reader's understanding of these. Due to the scope of this paper, only selected scenes and within these, selected examples can be discussed.

Loach deploys the characters' struggle with the social system as a device to criticise the British welfare system and demonstrates that "society's and individuals' beliefs about the responsibility for social exclusion tend to two extremes" (Madanipour et al. 2015, 6). I argue that the system's approach towards the individuals presented in the film closely resembles what Madanipour calls the 'underclass' approach: "One view is that individuals bring it upon themselves. [...] In this approach, people are blamed for their own poverty 
and/or social exclusion" (ibid., 6f). I will demonstrate that the protagonists are blamed for the situation they find themselves in and that this contributes to their experience of involuntary visibility within the film. At the same time, this unwanted visibility works as a powerful tool to engage the audience to generate compassion for the characters in I, Daniel Blake.

I will prove that while in a majority of scenes where representatives of the welfare system are involved, bald on-record strategies without any redressive action are used, showing little interest in maintaining the claimants' face, in those scenes where characters become visible outside of this system, empathy is shown through the use of politeness, demonstrating a sense of caring for the claimants' face. Through the use of invisible and visible spaces and scenes that offer the audience an exclusive view into the characters' emotional world, Loach manages to portray the welfare system and their executors in an even more intransigent manner.

\section{Visibility and Facework}

\section{Visibility}

In his article "Visibility. A Category for the Social Sciences", Andrea Brighenti (2007) argues that visibility should be considered as a general category for the social sciences (cf. 323). He states that empowerment is not one-sidedly linked to either visibility or invisibility but that it may rest with both categories (cf. ibid.). Moreover, he argues that "the relation of visibility is often asymmetric" (ibid., 326) which entails that seeing and being seen is not always equally present and that this transforms "visibility into a site of strategy" (ibid.). In I, Daniel Blake, this is often the case as the protagonists do not have access to the information, people, or concepts underlying the bureaucratic system they are struggling against. This asymmetrical relation is stressed, for example, through literacy: "As an individual claimant, Daniel has little control over the texts which define his access to resources. This is partly because these are invisible.” (Jones 2017, 405).

The characters in the film strive for recognition but fail to achieve this in the majority of scenes. They are often unable to control their own visibility. Brighenti draws attention to this aspect by noting that "visibility is closely associated to recognition [...] Visibility has to do with subjectification and objectification, with the onto-epistemological constitution of objects and subjects." (2007, 329). Daniel and Katie are mostly presented as objects in the public sphere and are only passive witnesses to their own exposure. I argue that the characters in the film are presented as belonging to a minority in 
the sense that they are excluded from the mainstream and that this is reinforced by linguistic structures used in the conversations. This is supported by Brighenti's idea that "recognition is a form of social visibility, with crucial consequences on the relation between minority groups and the mainstream” (2010, 239). Daniel is separated from the mainstream as expected by the system and thus actively exposed.

This leads to the concept of fair visibility. According to Brighenti, "there is a minimum and a maximum threshold [...] Below the lower threshold, you are socially excluded" $(2007,330)$ and "as you push yourself - or are pushed - over the upper threshold of fair visibility, you enter a zone of supra visibility, or super visibility, where everything you do becomes gigantic to the point that it paralyzes you" (ibid.). Characters in I, Daniel Blake experience minimum as well as maximum visibility in different contexts: the system exposes them and with that their assumed failure to provide for themselves. They are subsequently drawn into a grey area of social actions which remain unnoticed by the system but are well noticeable by the audience. It is this play with visibility within the film and towards the audience that lends the film its powerfulness and leaves no option for the audience than to emotionally engage with it.

In the film, the characters are portrayed as empowered as well as disempowered, which is backed up by Brighenti: "Visibility is a double-edged sword: it can be empowering as well as disempowering." (ibid., 335) but as soon as they become visible to the system, i.e. they become dependent on social benefits, they are disempowered in the public space. Here, Brighenti refers to Foucault: "In the disciplinary society, visibility means disempowerment. Namely, 'visibility is a trap' (Foucault 1977, as cited in Brighenti 2007, 336).

We witness the characters' struggle against an opaque system which has them experience the effects of power over others but conceals its true powerful nature, which is referred to by Brighenti:

Thus, power can be conceived as a form of external visibility (visibility of effects) associated with internal invisibility (Invisibility of identification): the effects of power are visible to everyone, but what power is in its essence, where it is really located, will not be disclosed. (ibid., 338)

I am especially interested in the ways in which linguistic strategies are employed in the film to highlight the impenetrability of the social system, as is witnessed by the protagonists Daniel and Katie: They both witness the effects of this system, such as monetary deprivations and public humiliation but never get to talk to those in the background. Susan Jones notes in this respect that "the film-makers foreground, in particular, the use of language as a feature of the impenetrability of the system” (Jones 2017, 405). 
Relating this to the topic of visibility, Brighenti asserts,
Whether in the form of recognition or in the form of control, the foun- dations of social power seem to be entangled with visibility issues. Once organised in regimes, asymmetries of visibilities serve ceaselessly to repro- duce the very power/knowledge asymmetries of which they are the prod- uct. (Brighenti 2010, 62)

These asymmetrical power relations are strongly linked to visibility issues in the context of poverty in the UK. Daniel witnesses these asymmetries especially when facing the welfare officers. "The exchanges across Job Centre desks also emphasise how little voice a claimant has within the system" (Jones 2017, 408). As Nick O'Brien states: "At its root, the film invites reflection in nothing less basic than the relationship between the individual and the state" (82).

\section{Face Work}

Together with Erving Goffman’s essay “On Face Work: An Analysis of Ritual Elements in Social Interaction" (1967), Brown and Levinson's framework for the analysis of politeness strategies (Brown and Levinson 1999) provides the defining approach in the field of politeness theory. According to Goffman, face can be "defined as the positive social value a person effectively claims for himself by the line others assume" $(1967,5)$. Brown and Levinson (1999) describe face as "the public self-image that every member wants to claim for himself” (311) and further distinguish between 'positive face' and 'negative face': while the latter stands for "the basic claim to territories, personal preserves, rights to non-distraction, i.e., to freedom of action and freedom from imposition" (ibid., 321), the former is defined as "the positive consistent self-image or 'personality' (crucially including the desire that this self-image be appreciated and approved of) claimed by interactants" (ibid.).

Brown and Levinson presuppose that all individuals tend to cooperate with each other and are intrinsically motivated to maintain each other's face by cooperating and mitigating face threats (cf. ibid.). This interdependence infers that "normally, everyone's face depends on everyone else's being maintained" (ibid.) which entails that everyone shares the same interest in avoiding threatening the interlocutor's face in order not to lose their own. In I, Daniel Blake, especially characters with higher social status and more power, as for example Sheila, the welfare officer, deliberately break with this in order to publicly humiliate claimants and address them in terms of the 'underclass' approach (cf. Manadipour et al.). 
Furthermore, face is referred to as 'basic wants,' a universal desire shared by all members of a society (cf. Brown and Levinson 1999, 312), relating to the Weberian notion of the term 'zweckrational' (instrumentally rational), suggesting that face respect is not an unequivocal right (cf. ibid.). Face work thus functions analogously to diplomacy, integrating good intentions but in many cases ignoring them, as in the case of actual immediacy, in favour of efficiency and during affronts (cf. ibid.). Goffman defines face work as "the actions taken by a person to make whatever he is doing consistent with face” $(1967,12)$.

Characters in the film often experience effrontery during the conversations at the job centre and these scenes shall be looked at in more detail. The complexity of interaction between positive face and negative face in I, Daniel Blake is a major feature regarding the category of visibility and its manifestations in the film. In accordance with these propositions, Brown and Levinson develop the idea that every speaker's and every addressee's face can be and is intrinsically threatened by "namely those acts that by their nature run contrary to the face wants of the addressee and/or of the speaker" (1999, 313).

'Face threatening acts' (FTA) are divided into positive and negative FTAs and threats to the hearer's versus threats to the speaker's face. Threats addressing the hearer's negative face want include e.g.: orders and requests, suggestions, advice, threats, warnings, offers. Threats that address the positive face include e.g.: disapproval, criticism, disagreements, irrelevance, taboos, non-cooperation (cf. ibid., 313ff.). Face threats to the speaker's negative face are i.e.: thanking someone, acceptance of addressee's thanks/apology, making an excuse, accepting offers. Face threats to the speaker's positive face are e.g.: apologising, accepting a compliment, self-humiliation, confessing of guilt, not having one's emotions under control (cf. ibid., 314ff.).

According to Brown and Levinson, each speaker chooses a strategy when deciding whether to do an FTA or not, responding to three universal face wants: "the want to communicate the content of the FTA [...], the want to be efficient or urgent [...], the want to maintain H's face to any degree" (ibid., 316, "H” relates to the hearer/addressee in the conversation). 
Figure 1 below demonstrates the possible strategies for (not) doing face threatening acts:

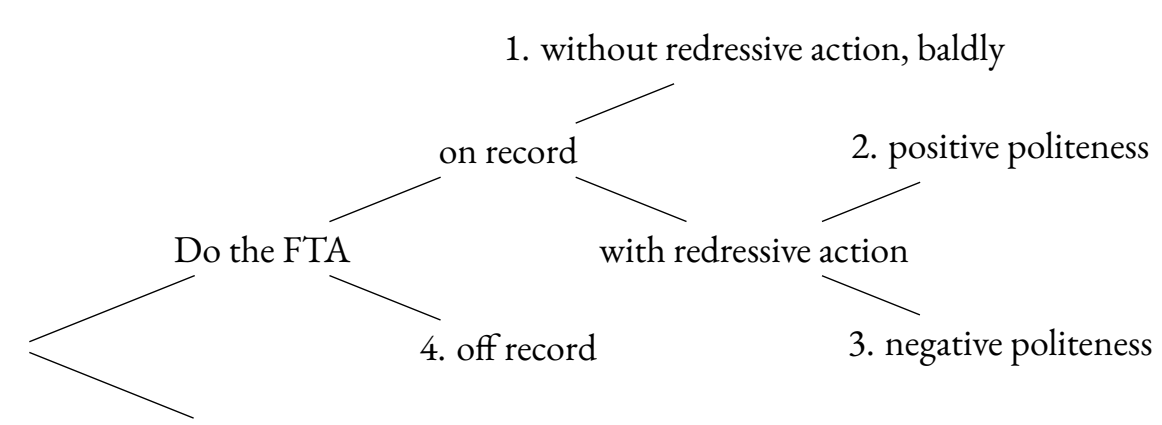

5. Don't do the the FTA

Figure 1: Possible Strategies for doing FTAs (Brown and Levinson 1999, 316)

The interlocutor can decide to do or not to do the FTA and if they decide to do it, it can be either 'on record' or 'off record' by simply making a hint. If the interlocutor decides to go on record, the FTA can be done with or without redressive action, where the former is linked to doing the FTA baldly and the latter is linked to giving "face to the addressee" (ibid., 317). When choosing to apply redressive action, the interlocutor can use positive politeness or negative politeness where the first "is oriented toward the positive face of $\mathrm{H}$, the positive self-image that he claims for himself” (ibid.) or using negative politeness which "is oriented mainly toward partially satisfying (redressing) H's negative face, his basic want to maintain claims of territory and self-determination" (ibid.).

When deciding for negative politeness, the interlocutor tries to avoid confrontations and reassures the hearer that he will not interfere with the other's freedom. This strategy is defined "by self-effacement, formality and restraint, with attention to very restricted aspects of H's self-image, centring on his want to be unimpeded” (ibid.). Both speaker and hearer try to smoothen the natural tension immanent in negative politeness through 'conventionalised indirectness,' which, according to Brown and Levinson (1999), is a compromise for FTAs that change from an indirect mechanism to an on record fully conventionalised one (cf. ibid.).

In the context of this paper, I will connect the sociological variables 'social distance,' 'relative power,' and 'absolute ranking' with the realisations of the category of visibility and face keeping/face threatening acts in the film.

According to Morand (2000), who illustrates the use of politeness in superior-subordinate communication, "politeness theory posits that power, social distance, and the intrinsic severity on an FTA, are all predictors of just how much remedial linguistic work an individual will use" (239). I intend to incorporate these values from a sociological 
point of view: Where Brown and Levinson argue that they are "not intended as sociologists' ratings of actual power, distance etc. but only as actors' assumptions of such ratings, assumed to be mutually assumed," (320) I will take into consideration the actual asymmetries and differences regarding power and status within the application of FTAs related to visibility and invisibility within I, Daniel Blake.

Power is defined as "an asymmetric social dimension of relative power" (Brown and Levinson 1999, 320). It describes the degree to which the hearer can "impose his own plans and his own self-evaluation (face) at the expenses of S's plans and self-evaluation.” (ibid., 321, "S" relates to the speaker in the conversation). Brown and Levinson (1999) assert that power generally comes from two sources

either of which may be authorized or unauthorized - material control (over economic distribution and physical force) and metaphysical control (over the actions of others, by virtue of metaphysical forced subscribed to by others). In most cases, an individual's power is drawn from both these sources (ibid.)

In I, Daniel Blake, the employees at the job centre and the administrative staff on the phones seize control over the claimants' lives, leading to substantial physical deprivation like the lack of food, forcing Daniel to sell his furniture and Katie to work at the brothel.

In his critical essay on Brown and Levinson's face work theory, Werkhofer (2005) argues that "polite language use has of course to do with real persons" (155) and he aims at a critical reconstruction of "Brown and Levinson's model with regard to its psychological and sociological implications" (ibid.). In his words, "politeness thus mediates between the individual and the social, motivating and structuring courses of actions as well as being instrumental in performing them" (ibid., 156). According to Werkhofer, "the polite utterance is then a compromise between saying as much as possible of what the speaker had actually been intending, on the one hand, and avoiding the risk of a social conflict, on the other" (ibid.). I argue that characters in the film who are part of the social welfare system, break with these communication standards and actively engage in provoking a social conflict with the claimants. Werkhofer asserts that the notion of politeness has undergone a change from being ruled by social forces to being governed by individual ones (cf. 2005, 156).

Watts (1992) claims that decisions on realisations of politeness are decided upon individually, which becomes evident when juxtaposing Sheila's and Ann's behaviour towards claimants at the job centre: While Ann treats Daniel with respect and dignity, trying to support him, Sheila strictly executes orders without humanity. Especially during the encounters across job centre desks, Sheila choses her FTAs partly because of the 
social construct she is embedded in, partly because of power differences between her and Daniel, and partly because it is her individual choice. Power imbalances are a decisive force in I, Daniel Blake and serve as a justification for those welfare system employees who mistreat the claimants.

Yabuuchi (2006) suggests that "power not only includes institutionalized power, but personal competence and skills, or economic wealth, which has a certain amount of influence over others even when there is no concrete promise of benefit for others" (328). The seriousness of politeness seems to be an issue influencing the use of politeness strategies in the film and politeness strategies are often only applied when not being sincere. Mills (2003) states that " $[\mathrm{i}] \mathrm{n}$ relation to politeness, assessment of the degree of sincerity or commitment of the politeness or impoliteness is crucial. However, within Brown and Levinson's model we have to assume that all politeness is sincere" (60). Referring to hierarchy politeness, Yabuuchi (2006) asserts that persons with a higher social ranking have the desire to be liked and therefore apply politeness strategies (cf. 330). Morand (2000) focuses on the variable of power in formal settings and suggests that more politeness strategies are used by subordinates (cf. 239ff.). This runs counter to the behaviour of some of the employees at the job centre in I, Daniel Blake and I argue that these use bald on-record strategies in order to prove their superiority, deliberately omitting redressive action.

\section{Masculinity}

The problems faced by the male protagonist Daniel are also partly related to the changing definition of the working- and middle-class in the UK. Connell (2005) notes that "new information technology became a vehicle for redefining middle-class masculinity at a time when the meaning of labour for working-class men was in contention" (80). Digitisation and its implications are limiting Daniel: His digital illiteracy is an obstacle deterring him from obtaining the support he is entitled to. Jackson (2016), focusing on working class men, asserts that these are "often neglected in the research literature or seen as archaic objects slightly unfashionable in a postmodern society” (124). Daniel, a former carpenter, moves downward to the bottom of society and experiences "an unequal distribution of life chances as well as feelings of lowered confidence and self-worth" (ibid.).

Connell (2005) argues that "the constitution of masculinity through bodily performance means that gender is vulnerable when the performance cannot be sustained" (54). He asserts that through the changes in technological development, skills formerly assigned to feminine jobs have now become part of the new masculinity: "The new information technology requires much sedentary keyboard work, which was initially classi- 
fied as women's work" (ibid., 55f.). In the film, Daniel's lack of physical as well as digital 'fitness' contribute to his social decline and lead to his unwanted and uncontrolled visibility (as his lack of knowledge of computers forces him into unpleasant debates with employees at the job centre and eventually requires him to seek assistance from others).

\section{Britain's Socio-Political Situation}

In order to frame the background of I, Daniel Blake, the socio-political situation in Britain at the time shall briefly be outlined. Set in Newcastle upon Tyne, director Ken Loach reflects on the post-2010 era as pointed out by Susan Jones: "The film depicts the impact of changes to the welfare system implemented by the Conservative-led coalition government in 2010" (2017, 399).

The changes in the British welfare system and the economic situation have become particularly visible in "the erosion of the British welfare state and the loss of support for the idea that caring for older people should be a collective responsibility" (Tulle 2004, as cited in Jackson 2016, 146).

Commenting on the situation of social housing in Britain, Shapely (2017) asserts:

In 2016, the number of households on the local authority waiting lists was still 1.18 million. This has gone down year on year since the 2011-2012 peak of over 1.8 million but is still above the 1997 figure of just over 1.1 million. The three main reasons for wanting to be rehoused were unsatisfactory living conditions (overcrowded and insanitary), health reasons and homelessness. (n. p.)

With the focus on the main character, Daniel, I, Daniel Blake "itself synthesises these stories into the simple narrative of one man and his thwarted attempts to access the benefits to which he is entitled whilst unable to work" (Jones 2017, 400) and condenses the stories of the lived realities of many Daniel Blakes in real life. Partially quoting Dorling (2015), Jones remarks that "in 2010, a Conservative-led coalition government came to power and the film depicts the effects of austerity politics in the UK. It was released at a time when 'growing income or wealth inequality is recognised as the greatest social threat of our times" (Dorling 2015, quoted in Jones 2017, 400).

Opposing the film's portrayal of British life in the early 2010s and neglecting the urgent necessity of the British welfare system to react to the needs of those depending on the welfare state, Conservative politician and Secretary of State for Work and Pensions in the 2010 coalition government, Iain Duncan Smith commented: "[T]he film 
has taken the very worst of anything that can ever happen to anybody and lumped it all together and then said this is life absolutely as it is lived by people, and I don't believe that." (Smith quoted in Watts 2016, n.p.)

According to Jones (2017), the consequences of these politics are poverty and marginalisation. The discourse of deficit and undeservedness foster a strategic deployment of ignorance within British society. She notes that media-friendly notions like 'shirkers' and 'strivers' are used instead of 'workers' and lead to negative associations with people reliant on the welfare system.

Poverty is exposed on various levels, presenting the main characters' struggle against the system. In many scenes, the characters' visibility - and with this also their poverty is linked to shame, exposure, and regulation by others.

\section{Selected Scenes Highlighting Involuntary Visibility}

Involuntary visibility and exposure in the film are linked to bald on-record politeness strategies with little efforts to maintain the hearers' (claimants') face, fostering exposure not only of the characters' poverty but blaming them for the situation they find themselves in. There is little interest in keeping the claimants' face and thus FTAs to both positive and negative face lead to the protagonists' exposure and involuntary visibility. These scenes, mainly situated at the job centre, are triggered by power asymmetries and different social statuses that are used to parade the claimants' inadequacy.

\section{Exposure Through Visibility and Power Hierarchies}

The original version of the film script (I, Daniel Blake, 2016. Scripts) used in the analysis did not include any indications on the speakers. I added abbreviated first names to clarify who is speaking. I also highlighted some sentences in bold to emphasise their importance in the context of the analysis.

Daniel's First Encounter with the Welfare System "Forget about me arse, that works a dream.”

Abbreviations:

A: Amanda

D: Daniel 
A: Good morning, Mr Blake. My name's Amanda. I've got a couple of questions here for you today to establish your eligibility for Employment Support Allowance. It won't take up much of your time. Could I just ask firstly, can you walk more than 50 metres unassisted by any other person?

D: Yes.

A: Okay.

A: Can you raise either arm as if to put something in your top pocket?

D: I've filled this in already on your 52-page form.

A: Yeah, I can see that you have but, unfortunately, I couldn't make out what you had said there.

D: Yes.

A: Can you raise either arm to the top of your head as if you are putting on a hat?

D: I've telt you, there's nowt wrong with me arms and legs.

A: Could you just answer the question, please.

D: Well, you've got me medical records. Can we just talk about me heart?

A: D'you think you could just answer these questions?

D: Okay.

A: So, was that a yes, that you can put a hat on your head?

D: Yes.

A: Okay, that's great. Can you press a button such as a telephone keypad?

$[\ldots]$

A: If we could just keep to these questions, thank you. Do you have any significant difficulty conveying a simple message to strangers?

D: Yes. Yes, it's me fucking heart.

D: I'm trying to tell you but you'll not listen.

A: Mr Blake, if you continue to speak to us like that that's not gonna be very helpful for your assessment. If you could just answer the question, please.

D: Yes.

A: Okay. Do you ever experience any loss of control leading to extensive evacuation of the bowel?

D: No. But I cannot guarantee there won't be a first if we don't get to the point.

A: Can you complete a simple task of setting an alarm clock?

D: Oh, Jesus. Yes. Can I ask you a question? Are you medically qualified?

A: I'm a health care professional appointed by the Department of Work and Pensions to carry out assessments for Employment and Support Allowance.

D: But there was a bloke out in the, er, in the waiting room, he says that you work for an American company. 
A: Our company's been appointed by the Government.

D: Are you a nurse? Are you a doctor?

A: I'm a health care professional.

D: Listen, I've had a major heart attack. I nearly fell off the scaffolding. I wanna get back to work, too. Now, please, can we talk about me heart? Forget about me arse, that works a dream.

In the opening scene of the film, which the audience can only hear but not see (as there is only a black screen), Daniel encounters the mechanisms of the welfare state for the first time and we are introduced to the linguistic impenetrability of the system. By definition, requests are a threat to one's negative face as the hearer's freedom from imposition is in danger. This is clearly evident as the hierarchical power difference between Daniel and the welfare employee is defined by asymmetric power relations. He is the claimant and dependent on his evaluation by the health care professional. The welfare employee uses bald on-record strategies by directly asking Daniel if he is capable of certain actions in order to evaluate his health status (i.e. "Can you complete a simple task of setting an alarm clock?"). When he refuses to cooperate, she uses negative politeness in order to proceed "If you could just answer the question, please." I would also like to draw attention to the employee's repeated use of "Okay." or "Okay, that's great" which is an affirmation of previous utterances made by Daniel and serves conversational politeness forms but is also a politeness strategy: The speaker risks an FTA to her own face by approving what was previously said and at the same time minimises a threat to Daniel's to negative face.

Daniel, on the other hand poses counter questions and through this actively threatens Amanda's positive face: When he asks her: "Are you medically qualified? Are you a nurse? Are you a doctor?" this implies his questioning of her professional qualification for the job and he goes bald on-record threatening her positive face as he challenges her public self-image. The FTA is introduced by a closed question ("Can I ask you a question?") which in any case results in an FTA for the hearer and the speaker. If she denies, this will result in a threat to the speaker's negative face and to the hearer's positive face and vice versa. Addressing taboo topics is a threat to the hearer's positive face and Daniel does so by naming his "arse", a word that is inappropriate in this context.

In this dialogue, the audience is introduced to the beginning of his continuing involuntary exposure and helplessness leading to uncontrollable negative visibility. In this scene, he is exposed to the audience and to the health care professional but his visibility towards other characters in the film is still limited. This changes during the next scene 
where FTAs are used on purpose in order to make the character involuntarily visible both to other characters and for the audience.

\section{Katie and Daniel at the Job Centre "I don't know why people like you do this job.”}

This scene depicts Katie's and Daniel's first encounter at the job centre, which is a powerful example for how voluntary ignorance of face work exposes the claimants.

\section{Abbreviations:}

K: Katie

S: Sheila

M: manager

K: So now you're gonna sanction me so, er...

$S:$ No, I'm not gonna sanction you.

K: I may not get any money for a month.

S: I'm gonna refer you to the decision maker and they'll make the decision on whether they're gonna sanction you.

K: That's ridiculous...

S: I'm not actually making the decision, they're gonna do that. And then if they do decide to sanction you, then you will take a $40 \%$ cut in your benefits.

$\mathrm{K}$ : I know what it is, I don't need you to explain it to me. I'm more than aware...

S: Well there isn't anything else anybody can do today. So what I'm gonna have to do is, look, I think I'm... I've decided to...

$\mathrm{K}$ : Are you gonna put me in for a sanction?

$S$ : I have to, I have to follow the rules. And the thing is if you're gonna, be aggressive with me then I'm gonna have to ask you...

K: It's not about me being aggressive.

$S$ : I'm gonna have to ask you to leave.

$\mathrm{K}$ : I'm trying to explain to you a situation and you don't care.

$S:$ Er, security. Security?

K: I don't know why people like you do this job.

$S$ : I'm referring you to the decision maker.

$\mathrm{K}$ : It's all the same thing.

S: I don't wanna hear your language.

K: I, I beg your pardon.

S: Listen, I, I'm sorry, love, but you're gonna have to leave. 
K: Yeah, all right, frankly, take your hands off me.

S: I'm gonna speak to the manager, I don't wanna speak to you. The fact is I'm just trying to explain...

S: Sorry?

K: I'm just explaining... Well it's not you I wanna speak to... You can go back up there.

M: Right, come and talk to me then if you've got something to say.

K: Okay. Sorry.

M: All right.

The passage is densely packed with face threats addressing the hearer's negative face, for example orders, requests, and warnings, some in a more polite form, others very bald onrecord: Sheila, the job centre employee, requests Katie to leave and threatens her with consequences should she not obey: "You have to do this.", "You need to leave the building.” (Sheila). By interrupting her, she actively threatens Katie's positive face. Other instances where Katie's positive face is ignored is the calling of security, which functions to end the conversation, actively demonstrating superiority over the conversational course and also works as a feature to expose Katie in public: "Er, security. Security?" (Sheila)

Inherent to the situation is of course the bringing of bad news and the ignorance of Katie's feelings: Sheila frequently uses expressions like "I'm gonna, I'll have to, I've decided" in order to impose her decision upon Katie. This threatens Katie's positive face as her feelings are completely ignored. On the non-linguistic level, this is reinforced by the raising of voices and aggressive gestures and mimics. These statements, including the reference to other instances in the welfare system, pushing one's responsibility towards those who remain invisible in the film, add to the power of FTAs when actively exposing claimants seeking for support.

When Katie asks for the manager and later tells him her address, she apologises ("Okay. Sorry.”), which can be interpreted as a damage to her own positive face, an urge to seek understanding and support. The manager, by accepting the apology ("All right.") damages his negative face and one could almost be misled to interpret this as a genuine acceptance of face loss. This though is pretence: He allegedly gives her space to explain her situation only to interrupt her afterwards, which demonstrates again that there is no concern to maintain the claimant's face in public, as can be read in the transcript below: 
Abbreviations:

K: Katie

M: manager

K: I've tried to explain to the woman, I've never been to Newcastle before. We've just moved up here from London. I've been here a few days, I don't know where I'm going. Okay? I was on the bus, it's gone the wrong way. We've run, got off the bus, run so that I wasn't any more late. She just don't wanna know and now she's telling me she's gonna refer me for a sanction.

M: What I want you to do is listen to me. Okay? The lady's told you what's right. There's rules here, rules that we have to stick to. Okay? It isn't against you, but you have a duty.

$\mathrm{K}$ : Oh, mate, listen, I'm not saying it's against me.

M: You have a duty to be here on time.

$\mathrm{K}$ : And I'm explaining to you why I wasn't here on time.

M: D’you know what? I understand, right...

K: I got lost.

M: But what I gather now is the decision maker... The decision maker's gonna be sending you a letter through the post. So you're gonna have to wait for that. And then nobody...

K: Yeah, I've got... My kids have gotta start school tomorrow. I've got about 12 quid in my purse.

M: D'you know what? All because you can't just calm down and listen to people when they talk. Right. You have to do this. Right, d'you know what, I've listened to you. You've created a scene.

$\mathrm{K}$ : With your rules.

M: I think you need to...

K: I've created a scene?

M: You need to leave the building.

In this scene, Katie is trying to explain her situation to the manager who again does not show any interest in maintaining Katie's face. After having listened to her explanation of the situation, he bluntly responds: "You have a duty to be here on time." When Katie explains that she was late because she had just moved there, he answers: "D'you know what? I understand, right..." just to blame the entire situation on her afterwards: "D'you know what? All because you can't just calm down and listen to people when they talk." This is bald on-record with damaging both her negative- and positive face, 
which goes way beyond the social role attributed to the manager in this case: The urge to be efficient and to communicate the conversational goal, which is that Katie needs to leave the building, is overruled by blaming the claimant for her situation, being an unemployed single mother of two.

On the hearer side, the job centre employees cleverly avoid threats to their positive face by not reacting to Katie's apologies. This indicates that politeness strategies are only accepted and played along with as long as the superior's patience or even ignorance allows and then to put a halt to it when one has had enough. Without paying any attention to the claimant's face, the situation results not only in a loss of face linguistically speaking but also on the actual social level. With regards to visibility, Katie is exposed in front of the other characters in the film and the audience.

Abbreviations:

K: Katie

M: manager

S: Sheila

D: Daniel

O: other claimant

D: Who's first in this queue?

Other: I am.

D: D'you mind if this young lass signs on first?

Other: No, no, you carry on.

D: There you go. Now you can go back to your desk and let her sign on and do the job that the taxpayer pays you for.

$\mathrm{K}$ : This is a bloody disgrace.

M: Listen, all right, this doesn't have to involve you. Everybody's trying to do their job here and you're creating more of a scene again.

D: But, look, you're not listening to her. She's out of the area. She's just been a few minutes... Can you not let her sign on? She's got two kids with her, man.

D: What's wrong with you people?

M: Right, listen, this isn't your concern. I want you to get out as well. All right? I need you to leave. We need to do this right. Yeah.

$\mathrm{K}$ : All right.

M: Listen, listen, listen...

K: They're just gonna call the police.

D: Phone the police? Can we get some perspective in here? 
M: You need to go or we're gonna phone the police. All right?

$\mathrm{K}$ : Come on. Thanks very much...

D: Can we have a bit of perspective, please, here, man?

S: Away, don't be silly.

D: Shouldn't even have this job.

K: Come on. Please.

D: Shouldn't even have this job.

M: Come on, get out.

When Daniel tries to help Katie and asks if any of the other claimants would be willing to let her sign up first, this again is sanctioned by Sheila and the manager, ultimately resulting in public exposure and the threat of calling the police. Daniel and Katie are forced to leave the job centre in order to avoid further action. Instead of cooperating with Daniel and responding to his questions, the manager uses FTAs in the form of advice, directives and future predictions, like "Listen, all right, this doesn't have to involve you. Everybody's trying to do their job here and you're creating more of a scene again" which subsequently turn into the more direct form of "Right, listen, this isn't your concern. I want you to get out as well. All right? I need you to leave." and ultimately "You need to go or we're gonna phone the police." Daniel threatens the manager's positive face by expressing his negative attitude to him "Shouldn't even have this job." while Katie cooperates with the manager and threatens Daniel's negative face by asking him to "Come on. Please." This indicates that Daniel would be willing to risk, both linguistically and on a situational level, more than Katie who tries to elude any further confrontation.

\section{First exchange with Sheila: "Do you want to sign this or not?"}

Abbreviations:

S: Sheila

D: Daniel

S: Daniel Blake? If you'd like to follow me, Mr Blake. If you'd like to just take a seat. This is the Claimant Commitment form. You must commit yourself to spending 35 hours a week looking for work. Now that can be newspapers, agencies, and online via the Universal Job Match.

Daniel encounters two different job centre employees: Sheila and Ann. In the scene above, Sheila abruptly switches between the invitational form "If you'd like," which is an offer indicating that Daniel is (theoretically) given a choice to decide whether or not 
he wants to do this, to "You must", which can be classified as a directive. This indicates that if he does not commit himself to this agreement, there will be negative consequences for him. This can also be classified as a switch from positive politeness more on the offrecord side to bald on-record as soon as matters are related to sticking to procedure.

S: You just fill in the details. But you must prove that you've done this as well, mind.

D: Well I've been told by my doctor that I'm not supposed to go back to work yet.

S: Then you should apply for Employment and Support Allowance.

D: I have, but I've been knocked back by some quack and now I'm trying to appeal.

S: Okay. Well that's your choice, Mr Blake.

D: No, it's not my choice. I've got no other form of income.

S: Do you want to sign this or not?

Sheila mainly uses positive politeness in this scene as she does not go bald on-record. Nonetheless, in terms of communicational cooperation, she ignores Daniel's arguments and, computer-like, sticks to the routine. Daniel actively decides not to cooperate with Sheila, by telling her that it is not his choice whether to sign the form and by this goes bald on-record. Her reaction by asking a question that leaves him no option but to sign can be classified as bald on-record again.

As if the conversation had not already been disgracing enough for the protagonist, the tone becomes even sharper:

S: You just need to put your signature here. I shall date it later on. Thank you. Now can I have a look at your CV?

D: "CV"?

S: You still don't get this, do you, Mr Blake? This is an agreement between you and the State.

D: No, you still don't get it.

S: No, you must...

D: I'm desperate to go back to work.

S: If you're desperate to get back to work... Unless the doctor tells us... You need to have an up-to-date $\mathrm{CV}$, in order to help you look for work. Now, just hold it right there. There's a CV workshop that I would like you to attend and it's this Saturday at 9:00.

D: No, thanks, I'll sort that out on me own.

$S$ : No, Mr Blake. This is a formal direction. You will attend if you want to proceed 
with your Jobseeker's Allowance claim.

$D$ : What happens if I don't?

S: Then you will be referred for a sanction.

In the scene above, bald on-record politeness combined with blaming the protagonist is used again in order to expose him. Sheila, as the manager before, moves from situationally appropriate language within the social context and the hierarchical differences to linguistic threats on the personal level. She does not seem to have any intention to maintain Daniel's face when telling him: "You still don't get this, do you, Mr Blake? This is an agreement between you and the State." (Sheila). On the linguistic level, this is an FTA indicating that he is intellectually not capable of understanding the consequences of his behaviour.

Blaming the protagonists for their situation is a common feature in the film and the usage of bald on-record politeness is a powerful linguistic feature that serves as a tool to actively criticise the treatment of claimants in the British welfare system.

This systematic verbal torture pushes Daniel into unwanted visibility and all attempts to do justice to the requests are denied by Sheila. The following scene takes place after Daniel has been applying for jobs "the old-fashioned way", meaning that he goes from door to door and speaks to possible employers leaving them his handwritten CV.

\section{Second Exchange with Sheila: "Well that's not good enough, Mr Blake."}

Abbreviations:

S: Sheila

D: Daniel

S: Well that's not good enough, Mr Blake. And how do I know you've actually been in contact with all these employers?

D: Well, I walked round the town. I gave out me CV by hand.

$S$ : Well, prove it.

D: How?

S: Well, did you get a receipt? Take a picture with your mobile?

D: With this? I give you my word that's what I did.

S: That's not good enough, Mr Blake. What about the Universal Job Match online?

D: I went to the library, there's my appointment card. Did my head in. And I tried my best.

S: It's not good enough. Can I look at your CV?

D: All right. 


\section{S: Did you not learn anything at the $\mathrm{CV}$ workshop?}

D: You'd be surprised. Not good enough, Sheila?

S: I'm afraid I'm gonna have to refer you to a decision maker for a possible sanction for four weeks. Your payment will be frozen. You may be entitled to Hardship Allowance if you apply. Do you understand? And if you are sanctioned, you must continue to look for work and sign on. If you don't, you may be sanctioned again. And it's likely to be for thirteen weeks on the second occasion, and thereafter. And likely to be the maximum of up to three years. Would you like me to write you a referral to a food bank?

The audience witnesses how little interest Sheila has in maintaining Daniel's face in this scene. She continues to go bald on-record in order to continue her task-oriented inquiry. Sheila demands proof of Daniel's activities on the job market after she had forced him to participate in a CV workshop. When Daniel tells her that he has applied for jobs by talking to possible employers and handing them his handwritten $\mathrm{CV}$, she repeatedly contests that this is not enough "Well that's not good enough, Mr Blake." Instead of using auxiliaries like "could" or "would", she goes for the direct question marker "Can I look at your CV?," also omitting the politeness feature "please" at the end of the question. This can be regarded as a technique to ensure linguistic efficiency and to demonstrate urgency, but it also indicates her lack of interest to maintain Daniel's face or the extent to which it is threatened. The entire scene continues in the same tone, with Sheila bald on-record and finishing with positive politeness by asking "Would you like me to write you a referral to a food bank?", leaving Daniel the option to maintain face to a certain extent.

Digital illiteracy is not regarded as a generational issue in this context but is negatively stigmatised in the same manner that illiteracy is. There are instances in the film where the characters are treated differently, gaining positive visibility towards their interlocutor. The character of Ann, who stands for empowerment and empathy, and the face work between her and Daniel, shall be examined in the following section.

\section{Empowerment/Voluntary Visibility}

Characters in the film not only experience negative visibility and exposure linked to public shaming but also empowerment and help. In the film, Loach criticises the failures of the British welfare system, but he also shows that while the system itself may be broken, some of its 'pieces' may still be functional. One 'piece' in this system is represented by 
the character of Ann who demonstrates that there are still human traits in the digitalised world of welfare care. She repeatedly tries to find exits to support Daniel and keep him within the system. Ultimately, she does not succeed as Daniel decides to fight for his claims and goes off benefits.

\section{Ann and Daniel: "Jesus, I've got you into trouble now."}

Abbreviations:

A: Ann

D: Daniel

Sup: Ann's superior

A: Do you have a partner?

D: Er, no. She, er, she's passed away.

A: Oh, I'm really sorry to hear that.

D: Thank you.

A: D'you have any dependent children aged under 20 living with you?

D: No, I don't.

A: It's really important we get this filled in because we need to get the process started.

D: Yeah.

Sup: Excuse me, Ann. Can I have a word, please?

A: Could you just give me $\mathbf{3 0}$ seconds, please? We're just getting...

Sup: Well, actually, can I have a word now, in my office? Thank you.

A: Right.

D: Jesus, I've got you into trouble now. I'm really sorry.

A: It's me that should be sorry. You just carry on, you're doing good.

Sup: You know, Ann, we've spoke about this before. That isn't acceptable.

A: I think in this case it's quite reasonable...

Sup: Come on in the office.

Sup: The thing is you're setting a precedent. It's not acceptable.

In contrast to Sheila, Ann feels empathy for Daniel and tries to support him on several occasions. In these exchanges, Daniel's self-respect is paid attention to, and his face wants are addressed. For showing empathy and supporting Daniel, Ann is actively sanctioned by her superior and called to the office. This is witnessed by job centre staff, security, and other claimants, leading to involuntary visibility and exposure of not only Daniel but also of Ann. 
Ann uses politeness strategies in order to gain the information needed for Daniel to fill out the Claimant Commitment Form. She asks him about his family status. When learning that his wife has died and he does not have any children, she expresses her compassion, which Daniel responds to with a complimentary note ("I'm sorry to hear that. - Thank you."). Both interlocutors risk and try to maintain each other's faces here. This instance is an exception to the conversations between claimants and the representatives of the welfare system and an example of sincerity and compassion. Ann literally risks her face to help Daniel maintain his.

When Ann's supervisor tells her to come to her office, Daniel apologises: "I'm really sorry." (Daniel) and she responds, "It's me that should be sorry." (Ann), taking upon her the guilt of the welfare system for the poor treatment of their clients. Having more than a linguistic meaning, her apology stands for the entire malfunctioning system that blames claimants for their situation and on top of that fails to assist them when already trapped in the all-pervasive net of social injustice.

Ann and Daniel: "I've seen it before. Good people, honest people, on the street.”

Abbreviations:

A: Ann

D: Daniel

A: So, what jobs have you actually applied for?

D: It's a monumental farce, isn't it? You sitting there with your friendly name tag on your chest, Ann, opposite a sick man looking for non-existent jobs, that I can't take anyway. Wasting my time, employers' time, your time. And all it does is humiliate me, grind me down. Or is that the point, to get my name off those computers? Well, I'm not doing it anymore. I've had enough. I want my date for my appointment for my appeal for Employment and Support.

A: Have you not had that yet?

D: No.

A: Please listen to me, Dan. It's a huge decision to come off JSA without any other income coming in. Look, it... It could be weeks before your appeal comes through. You see, there's no time limit for a mandatory reconsideration.

D: I've got a time limit.

A: And you might not win. Please, just keep signing on. Get somebody to help you with the online job searches. Otherwise, you could lose everything. Please don't do this. I've seen it before. Good people, honest people, on the street. 
D: Thank you, Ann. But when you lose your self-respect, you're done for.

In contrast to the previous conversations with Sheila, Ann asks Daniel in a neutral manner what jobs he has already applied for. Daniel, apparently full of frustration, ignores any politeness strategies and, instead of answering, counters: "It's a monumental farce, isn't it? [...] I've had enough.” This is a bald on-record threat to threaten Ann's positive face without any redressive action. Ann responds by not sanctioning Daniel but accepts this offense as the cry for help that it is and offers him a way out instead by almost beseeching him not to go off financial support "Please, just keep signing on" (Ann). She does not impose sanctions on him and only slightly threatens his negative face. In order to fortify her advice, she turns to a prediction of his possible future "Otherwise, you could lose everything." (Ann) to continue with a request "Please, don't do this.” (Ann) and closes with a general statement "I've seen it before. Good people, honest people, on the street" (Ann). In the last sentence, she intriguingly makes clear that she does not blame Daniel as being responsible for his situation but that he is the victim of a malfunctioning welfare system. In contrast to the other employees, Ann stays off-record and tries to minimise face threatening acts towards Daniel.

\section{Empathy and Care}

Outside the context of the job centre, especially between Katie and Daniel, the shared interest as described by Brown and Levinson in caring for each other's face is present in a majority of scenes. Politeness strategies applied here include less examples of purely bald on-record strategies but more examples on-record with redressive action and offrecord politeness. The characters try to avoid causing exposure and public humiliation by avoiding face threatening acts. There is only one exception where one character linked to exposure himself - Daniel - decides to confront Katie about her decision to work as a prostitute. However, he chooses to go to the brothel and not to confront her at her house within her private sphere. This represents an act of keeping her decision invisible between the two of them and demonstrates that he is not blaming her for having chosen this path. Loach invites the audience to critically reflect upon the pressure of a woman not being allowed to be 'just' a mother.

\section{Katie and Daniel at the Food Bank “Okay, it's all right.”}

Katie and her children receive food stamps to get groceries at the local food bank. Daniel accompanies them and they wait at the end of a long queue in front of the building. 
When it is their turn, they are welcomed warmly, and the kids are offered tea and biscuits. I decided to keep this rather long passage, as it powerfully demonstrates the usage of politeness strategies in order to minimise face loss. While Daniel is waiting at the entrance, Katie is taken through the food bank and is helped with the supplies and groceries.

Abbreviations:

K: Katie

D: Daniel

Ag: Agnes

J: Jackie

Wom: employee food bank

Dai: Daisy

Wom: Is it just food for yourself and the two children, Katie?

K: Thank you.

Wom: Would your children have a drink of juice and a biscuit? Would you like to go and see Agnes? Agnes? Could you do a juice and a biscuit, please? Jackie?

J: Yeah.

Ag: Would you be able to help Katie with her shopping today, please?

Ag: There you are.

K: Thank you.

J: Hiya, Katie.

$\mathrm{K}$ : Thank you.

The above passage indicates that Katie is being treated as an equal human by the food bank employees: By using polite questions structures like "would you" or "could you" the employees signal that they take their clients seriously.

J: Right. I'll give you one side and we'll share it, yeah? Couple of onions. Is there anything we can do for you, hun? [...]

$\mathrm{J}$ : And then you tell me what you don't need, yeah? Have you got any sanitary towels? $\mathrm{K}$ : We don't have sanitary towels, no.

J: No? All right, not to worry. It's all right. Don't really donate things much like that.

K: Yeah.

J: It's a shame, they should. Right, right, if you open your bag. Rice? And a couple of 
toilet rolls?

$\mathrm{K}: \mathbf{M m m}-\mathbf{h m m}$.

$\mathrm{J}$ : Yeah? We'll go to the food.

$[\ldots]$

K: Okay, thank you.

J: Erm, there's pasta sauce over here.

$\mathrm{K}: \mathbf{M m m}-\mathbf{h m m}$.

J: I'll get you some pasta sauce? The pasta sauce... And there's, er, pasta here as well. I'll get you a pasta. Hey, pet, are you all right? What are you doing? What are you doing? Come and sit down. It's all right. It's all right, it's all right. Come and sit down. Come and sit down, it's all right.

$\mathrm{K}: \mathrm{Oh} .$.

J: Okay, it's all right. It's all right, it's all right. It's all right. D'you want a drink? D'you want a drink?

$\mathrm{K}$ : I'm really sorry...

Wom: What's the matter?

J: It's okay, don't worry. I'll get you a drink.

Dai: Mum, what's going on?

K: It's okay. It's okay I'm just really hungry. Okay, don't look at me.

D: No, no, no, it's okay, it's okay. There's no harm done.

K: I can't cope, Dan. I feel like I'm going under.

J: Look, you'll get through this, darling.

$\mathrm{K}$ : Thank you.

J: You'll get through this.

D: Katie, listen to me. This isn't your fault. You've done amazing. Dumped up here, on your own with two kids. You've done nothing to be ashamed of. Come on, you're okay. Come on, wipe yourself. Come on... You're okay.

$\mathrm{K}$ : If my mum could see me...

When Katie is taken through the food bank, she becomes increasingly pale and turns very quiet. The suspense created by this is released when she opens a tin of beans and starts eating with her bare hands, spilling food all over herself. The food bank employee steps in, Katie cannot hold herself together anymore and starts crying. Instead of blaming her and making the situation even more shameful for Katie, she assists her and repeatedly consoles her by stating that everything is okay. This can be classified as an instance of positive politeness as the employee tries to give Katie a sense of closeness. By indicating that her behaviour is not judged, she addresses Katie's wants and the need to be 
consoled and confirmed. Daniel further reassures her that she has done nothing wrong, which can be read as a strategy to comfort her and, on the other hand, to justify his own very similar situation by reinforcing the idea that being unemployed is not his fault. By referring to the state as the responsible instance, Daniel relocates the guilt away from Katie and himself, trying to keep face.

\section{Daniel Confronting Katie "I've built you a bookcase."}

After Katie has been caught shoplifting toiletries, the security employee Ivan gives her his number to contact him in case she should need help. It turns out that he refers her to a brothel. An incident including Daisy (Katie's daughter) who reveals that she had been bullied at school because her shoes had fallen apart again triggers Katie's decision to start working as a prostitute. When Daniel finds out, he hesitates to confront Katie but ultimately decides to talk to her at the brothel. Katie had previously told Daniel that she would like to finish school and he has built her a bookshelf.

Abbreviations:

K: Katie

D: Daniel

K: Oh, no, Dan.

D: Katie, you don't need to do this.

K: You shouldn't see me like this.

D: I'm sorry.

$\mathrm{K}: \mathrm{No}$, this, this is cut off. This is separate. Can you... You need to get out.

D: Listen, I couldn't speak to you in the flat, I need to speak to you now.

K: Dan, please, get out.

D: Oh, Katie, please, I need to speak to you. I just wanna speak to you. Katie!

K: Dan, please, just go.

K: Dan, please, I don't want you here! Will you just go, please!

D: I've built you a bookcase.

K: What?

D: For your books.

K: Oh, Dan. Please, just go. Please, just go, I don't want you here.

$\mathrm{D}$ : This is breaking my heart.

K: Dan, please, just leave me alone. I've got 300 quid in my pocket. I can buy the kids fresh fruit. If you can't deal with it, I can't see you anymore. Listen, I've gotta go back inside. D'you understand? I don't wanna speak to you anymore. And don't 
show me any more love. Cos you're gonna break me, Dan.

D: I don't understand.

Instead of going bald on-record, Daniel uses negative politeness in order to redress the utterance and to interact with Katie without imposing his opinion or his wish for her to quit at the brothel too much on her. In telling her that she does not have to do this and that he simply wants to talk to her, he leaves her the option to negotiate. Furthermore, by not directly using words related to prostitution, he maintains both her and his own face. The word "this" does only indirectly refer to the act of having intercourse with men for money. An off-record strategy applied by Daniel is the reference to the bookshelf he has built for Katie: Daniel indicates here that there are other ways for her and that he would prefer her to go back to school, which Katie had mentioned in several previous conversations throughout the film.

Katie's utterances gradually become more direct and tend more to the on-record side of politeness. She starts by telling him that he should not see her that way, moves on to telling him that she cannot talk to him, to finally threatening him to cancel their contact should he not be able to cope with her choice of occupation. This, of course is an active threat to Daniel's face but it seems to be happening because Katie is so desperate that she accepts the loss of her own face in order to be able to support her child financially. In contrast to the scenes at the job centre, moving towards bald on-record in this scene is merely an attempt from Daniel's side to rescue Katie from prostitution and his choice to confront her within the setting of the brothel suggests that he separates the confrontation from her personal life, thus indirectly helping her maintain her face in the private setting.

\section{Katie and Daniel in Court "You're gonna win this, Dan."}

Towards the end of I, Daniel Blake Katie accompanies Daniel to meet his solicitor in court. Reassuring him that his appeal will be heard and will lead to a positive outcome, the solicitor explains that his chances are very good. Although we are presented with a discourse between individuals of different social statuses, this short conversation varies immensely from those at the job centre. While it is, of course, the solicitor's job to represent Daniel in court it is more than likely that he is a court-appointed counsel. Nevertheless, his politeness strategies aim very much at keeping Daniel's face. 
Abbreviations:

Sol: Solicitor

D: Daniel

K: Katie

D: Hi, er, Daniel Blake. I've come for my appeal for the reinstatement of my... Employment and Support Allowance.

Sol: Daniel, hi. Hello. Are you all right?

D: Hello.

K: Hi, I'm Katie. I'm a friend of Daniel's.

Sol: Hi. You're here for support, yeah?

D: Yeah.

Sol: Daniel, your appeal will be heard by a legally qualified chairperson and a doctor.

D: Aye, fingers crossed.

Sol: Yeah...

D: If I lose this appeal, I'm out on the streets.

Sol: Well, we've got some updated reports here from your GP, your own consultant and your physiotherapist. And they're all furious. You're gonna win this, Dan. I do this every week. I bet me life on it.

K: I told ya.

Sol: Just be yourself, answer the questions and relax. I'm really confident. D'you have any questions?

D: Well, I've got one or two things I'd like to get off me chest.

$\mathrm{K}$ : But will they listen?

Sol: It's the least they can do.

The solicitor greets Daniel appropriately and gets to the point very quickly: Daniel's appeal will be heard, and his doctors are furious over the sanctions that have been imposed on him. The utterances "I do this every week. I bet my life on it." and "Just be yourself." are meant to reassure Daniel that his situation is not his fault. "Answer the questions and relax." is a request which should be threatening Daniel's negative face but the intention here is to reassure him of his rightful claim. When Katie asks if they would listen, the solicitor answers "It's the least they can do." which is an off-record strategy referring to the entire wrong-going of Daniel's case. 


\section{"I am a citizen, not a number."}

This paper set out to demonstrate how linguistic strategies influence the characters' visibility in I, Daniel Blake. By analysing highlighted scenes according to face work theory combined with Brighenti's theory on visibility, I hope to have proven that bald onrecord strategies are used mainly in the setting of the job centre by those employees who do not show empathy and support. They stand for the harshness of the British social welfare system and all its failures. On a linguistic level, bald on-record strategies with little to no redressive action with regard to the claimants' face are used in a majority of scenes. In this context, the employees at the job centre do not show any interest in maintaining the claimants' face, which also results in risking their own face. Furthermore, apart from the differences in power relations and hierarchy status, the choice of strategies cannot be solely attributed to the characters' social status, as Ann, also employed by the state, individually chooses to treat Daniel with respect and dignity. Outside the job centre setting, in conversations between the protagonists, at the food bank, and in court, keeping face plays a more important role and interactants try to minimise face threats even though differences in power and social status, as, for example, between the employees at the food bank, do play a role.

With regards to the category of visibility and its realisations as involuntary and negative versus voluntary and positive, I intended to demonstrate that bald on-record strategies are used in order to forcefully expose and humiliate as well as exercise control over the claimants, whereas politeness strategies trying to minimise face threats are used in those situations where individuals feel empathy and compassion for each other.

\section{References}

Brighenti, Andrea Mubi. 2007. "Visibility: A Category for the Social Sciences." Current Soci$\operatorname{ology} 55$ (3): 323-342.

Brighenti, Andrea Mubi. 2010. Visibility in Social Theory and Social Research. Basingstoke: Palgrave Macmillan.

Brown, Penelope and Stephen Levinson. 1999. "Politeness: Some Universals in Language Usage.” In The Discourse Reader, edited by A. Jaworski and N. Coupland, 311-322. London and New York: Routledge.

Connell, R.W. 2005. Masculinities. 2nd edition. Cambridge: Polity Press.

Dorling, Danny. 2015. Injustice: Why Social Inequality Still Persists. Revised Edition. Bristol: Policy Press.

Foucault, Michel. 1977. Discipline and Punish. New York: Pantheon. 
Goffman, Ervin. 1967. Interaction Ritual. Essays on Face-to-Face Behavior. New York: Doubleday and Company Inc.

I, Daniel Blake, 2016. Dir. Ken Loach.

I, Daniel Blake, 2016. Scripts. Accessed 7 July 2020. https://www.scripts.com/script/i\%2C_ daniel_blake_10556.

Jackson, D. 2016. Exploring Aging Masculinities. Basingstoke: Palgrave Macmillan.

Jones, Susan. 2017. “'Words of Wisdom': Text, Voice and Justice in I, Daniel Blake.” Changing English 24(4): 399-412.

Madanipour, A. et al. 2015. “Concepts of Poverty and Social Exclusion in Europe." Local Economy 30 (7): 1-21.

Mills, Sarah. 2003. Gender and Politeness. Cambridge: Cambridge University Press.

Morand, David A. 2000. "Language and Power: An Empirical Analysis of Linguistic Strategies Used in Superior-Subordinate Communication.” Journal of Organizational Behavior (21): 235-248.

O’Brien, Nick. 2018. “Administrative Justice in the Wake of I, Daniel Blake.” The Political Quarterly 89 (1): 82-91.

Shapely, Peter. 2017. "Britain's Hundred-Year Housing Crisis: A Century of Uneven Spending”. In History and Policy, edited by Alastair Reid et al., 06 October 2017. Accessed 7 July 2020. www.historyandpolicy.org/opinion-articles/articles/britains-hundred-year-housing-crisisa-century-of-uneven-spending.

Tulle, Emmanuelle. 2004. Old Age and Agency. New York: Nova Science Publishers.

Watts, Joe. 2016. “I, Daniel Blake: Iain Duncan Smith Slams Ken Loach’s Benefits Sanctions Film”. The Independent, 28 October 2016. Accessed 7 July 2020. www.independent.co.uk/ news/uk/politics/i-daniel-blake-iain-duncan-smith-ken-loach-response-criticism-benefits-san ctions-film-unfair-a7384306.html.

Watts, Richard J. 1992. Politeness. Key Topics in Sociolinguistics. Cambridge: Cambridge University Press.

Werkhofer, K.T. 2005. "Traditional and Modern Views: The Social Constitution and the Power of Politeness.” In Politeness in Language, edited by R. J. Watts, 155-202. Berlin: de Gruyter.

Yabuuchi, Akio. 2006. "Hierarchy Politeness: What Brown and Levinson refused to see." Intercultural Pragmatics 3-3: 323-351. 